ISSN $: 2302-1590$

E-ISSN : $2460-190 X$

\title{
ECONOMICA
}

Journal of Economic and Economic Education Vol.4 No.1 (52-60)

\section{PENGARUH STATUS SOSIAL EKONOMI ORANG TUA DAN MOTIVASI ORANG TUA TERHADAP TINGKAT PENDIDIKAN ANAK PEDAGANG TOKO/KIOS DI PASAR RAYA KOTA PADANG}

\author{
Desi Areva \\ Dosen Program Studi Pendidikan Ekonomi STKIP- PGRI Sumbar \\ Jl. Gunung Pangilun No.1, Padang Sumatera Barat \\ Email : desiareva@yahoo.co.id \\ submited: 2015.08.01 reviewed: 2016.06.16 accepted: 2016.06.23 \\ http://dx.doi.org/10.22202/economica.2015.v4.i1.270
}

\begin{abstract}
Abstract: The preliminary study toward the Merchants at Pasar Raya Padang, showed that the level of education of their children was still low. It was indicated by limited number of children who graduated from Senior High School and a few of them graduated from University. This condition was influenced by parents' education, income, and motivation. This research was aimed to discovered: 1) the influence of parents' level of education toward their income in Pasar Raya Padang, 2) the influence of parents' level of education and income toward their motivation in Pasar Raya Padang, 3) the influence of parents' level of education, income, and motivation toward their children level of education in Pasar Raya of Padang. The research was conducted under ex-post-facto design. The population was merchants stores with total number 2.337 and the sample was 343 which was taken by using purposive sampling. The data was collected through the questioner given to the sample which then analyzed statistically using path analysis. The data analysis showed that 1) parents' level of education significantly influenced their income. It showed that the parents' level of income was influenced by the level of education. 2) Parents' level of education significantly influenced their motivation. It showed that parents' motivation was influenced by their level of income as well as their level of education. 3) Parents' level of education, income and motivation significantly influenced their children level of education in Pasar Raya Padang.
\end{abstract}

\begin{abstract}
Abstrak
Penelitian ini bertujuan untuk mengetahui dan menganalisis: 1) Pengaruh tingkat pendidikan orang tua terhadap tingkat pendapatan orang tua (pedagang) toko/kios di Pasar Raya Kota Padang, 2 Pengaruh tingkat pendidikan orang tua dan pendapatan orang tua terhadap motivasi orang tua (pedagang) toko/kios di Pasar Raya Kota Padang, 3) Pengaruh tingkat pendidikan orang tua, tingkat pendapatan orang tua, dan motivasi orang tua terhadap tingkat pendidikan anak pedagang toko/kios di Pasar Raya Kota Padang. Jenis penelitian dalam penelitian ini adalah expostfacto, populasi adalah keseluruhan pedagang toko/kios di Pasar Raya Kota Padang yang berjumlah 2.337 pedagang toko/kios. Teknik pengambilan sampel purposive sampling yaitu sebanyak 342 orang. Teknik analisis data yang digunakan untuk membuktikan dan menguji hipotesis yang diajukan adalah path analisys. Hasil penelitian ini menemukan bahwa : 1) Tingkat pendidikan orang tua berpengaruh signifikan terhadap tingkat pendapatan orang tua (pedagang) toko/kios di Pasar Raya Kota Padang, 2) Tingkat pendidikan orang tua dan pendapatan orang tua berpengaruh signifikan terhadap motivasi orang tua (pedagang) toko/kios di Pasar Raya Kota Padang, 3) Tingkat pendidikan orang tua, tingkat pendapatan orang tua, dan motivasi orang tua berpengaruh signifikan terhadap tingkat pendidikan anak pedagang toko/kios di Pasar Raya Kota Padang.
\end{abstract}

Keywords: Parent Social Economics, Parent Motivation, children level of education. 


\section{PENDAHULUAN}

Orang tua, masyarakat, dan pemerintah merupakan tiga unsur penting yang bertanggung jawab dalam tercapainya keberhasilan dalam sebuah pendidikan. Masyarakat dan pemerintah bertugas menyiapkan sarana dan prasarana untuk diselenggarakannya proses pendidikan, seperti kampus, dosen, pegawai yang mengurusi administrasi kampus dalam suatu perguruan tinggi. Sedangkan orang tua mempunyai peran untuk memenuhi kebutuhan pendidikan anaknya. Di Indonesia banyak sekali orang tua yang tidak mampu untuk memenuhi kebutuhan pendidikan anaknya yang serba mahal. Bahar dalam Yerikho (2007:45), menyatakan bahwa: pada umumnya anak yang berasal dari keluarga menengah ke atas lebih banyak mendapatkan pengarahan dan bimbingan yang baik dari orang tua mereka. Anak-anak yang berlatar belakang ekonomi rendah, kurang dapat mendapat bimbingan dan pengarahan yang cukup dari orang tua mereka, karena orang tua lebih memusatkan perhatiannya pada bagaimana untuk memenuhi kebutuhan sehari-hari.

Orang tua yang berstatus sosial rendah akan mengalami kesulitan untuk memenuhi kebutuhan pendidikan anaknya, sehingga mengakibatkan anak tersebut sulit untuk mendapatkan informasi dari luar karena mereka tidak di dukung oleh fasilitas-fasilitas yang serba modern dan mereka tidak di dukung oleh keuangan yang cukup untuk membeli buku dan perlengkapan kuliah lainnya, mereka bisa makan saja bersyukur apalagi bisa beli buku. Dan kebanyakan dari mereka yang berlatar belakang dari keluarga yang tidak mampu secara ekonomi itu banting tulang untuk mendapatkan tambahan uang kuliah agar dapat membantu orang tua mereka. Di dalam sebuah proses pembelajaran diperlukan sarana penunjang yang terkadang mahal. Akibatnya bagi orang tua yang tidak mampu memenuhi sarana penunjang tersebut, maka anak akan terhambat dalam proses pembelajaran. Dengan demikian, sumber daya manusia menjadi rendah sehingga menghambat kemajuan bangsa dan negara.

Menurut Bahar (2000:131) tingkat pendidikan anak mempunyai korelasi yang tinggi dengan tingkat sosial ekonomi orang tua, sebab segala kebutuhan anak yang berkenaan dengan pendidikan selalu membutuhkan sosial ekonomi keluarga, dengan artian secara umum bahwa pendidikan membutuhkan uang untuk meningkatkan pendidikan anak. Menurut Tan faktor-faktor yang mempengaruhi sosial ekonomi orang tua meliputi: pendidikan, pendapatan, dan pekerjaan orang tua. Jadi orang tua yang memiliki sosial ekonomi yang tinggi akan lebih meningkatkan pendidikan anaknya. Selanjutnya Tarigan (2004:222) menyatakan manfaat pendidikan adalah adanya peningkatan tingkat pendapatan apabila mengikuti pendidikan yang lebih tinggi jenjangnya dan anak didik secara sadar atau tidak sadar akan menebarkan pengetahuannya kepada masyarakat sekitarnya.

Bentuk sektor ekonomi masyarakat perkotaan salah satunya adalah perdagangan. Pedagang adalah orang atau badan membeli, menerima atau menyimpan barang penting dengan maksud untuk dijual, diserahkan atau dikirim kepada orang atau badan lain baik yang masih berwujud barang penting asli, maupun yang sudah dijadikan barang lain. (Pasal 1 Angka 2 UU Nomor 29 Tahun 1948 Tentang Pemberantasan Penimbunan Barang Penting).

Berdasarkan hasil observasi penulis pada Dinas Pasar Raya Padang, pedagang dikategorikan pada 3 (tiga) jenis yaitu pedagang toko/kios, Petak Meja Batu, dan PKL (Pedagang Kaki Lima). Sektor ekonomi ini banyak digeluti masyara-kat di Kota Padang. Meskipun yang berprofesi di sektor ini tidak semua merupakan warga Kota Padang asli. 
Berdasarkan hasil observasi penulis pada hari Sabtu tanggal 19 Oktober 2013 kepada 30 orang pedagang terlihat bahwa tingkat pendidikan pedagang, jumlah tanggungan keluarga, pendapatan orang tua, motivasi orang tua, dan pendidikan anaknya beragam.

Hasil studi pendahulua dari 30 orang pedagang jika dilihat dari kepala rumah tangga banyak yang berpendidikan tamat SLTA dan pendidikan untuk ibu rumah tangga banyak berpendidikan tamat SLTA. Berdasarkan hasil survei awal terlihat bahwa pedagang rata-rata berpendidikan tamat SLTA. dari 30 orang pedagang sebanyak 18 orang $(60 \%)$ anak pedagang tamat SMA. Sehingga dapat dikatakan bahwa dari 30 orang pedagang pada survey pendahuluan ini banyak pedagang yang anaknya memiliki pendidikan hanya tamat SMA.

Tingkat pendapatan pedagang beragamragam, 21 orang $(70 \%)$ pedagang berpendapatan diantara 1 juta sampai 5 juta, 5 orang $(16,67 \%)$ pedagang berpendapatan $5 \mathrm{jt}$ sampai $10 \mathrm{jt}, 1$ orang $(3,33 \%)$ pedagang berpenghasilan 15 jt sampai 20 juta, dan hanya 3 orang $(10 \%)$ pedagang berpenghasilan di atas 20 juta.

Selanjutnya berkaitan dengan motivasi orang tua dalam pendidikan anaknya, berdasarkan hasil survey pendahuluan kepada 30 orang pedagang terlihat pada Tabel 1.4 berikut ini. motivasi orang tua masih kurang maksimal, hal ini terlihat bahwa orang tua dalam memberikan perhatian, pemberian hadiah untuk menyemangati anaknya, pemberian hukuman jika anaknya melanggar aturan, dan juga pemberian nasehat rata-rata masih kadang-kadang dilakukan oleh orang tua.

Tujuan yang ingin dicapai dalam penelitian ini adalah untuk mengungkapkan hal sebagai berikut: (1) Pengaruh tingkat pendidikan orang tua terhadap tingkat pendapatan orang tua (pedagang) toko/kios di Pasar Raya Kota Padang, (2) Pengaruh tingkat tingkat pendidikan dan pendapatan orang tua terhadap motivasi orang tua (pedagang) toko/kios di Pasar Raya Kota Padang, (3) Pengaruh tingkat pendidikan orang tua, tingkat pendapatan orang tua, dan motivasi orang tua terhadap tingkat pendidikan anak pedagang toko/kios di Pasar Raya Kota Padang.

Fattah (2009:16) menyatakan "pada dasarnya teori human capital yaitu suatu aliran pengeluaran yang menganggap bahwa manusia merupakan suatu bentuk kapital sebagaimana bentuk-bentuk kapital lainnya". Human capital ini dapat diaplikasikan melalui berbagai bentuk investasi SDM diantaranya pendidikan formal, pendidikan informal, pengalaman kerja, kesehatan, gizi serta transmigrasi. Senada dengan pendapat sebelumnya, Yahya (2009:205) juga menyatakan bahwa "human capital adalah kekayaan yang menghasilkan investasi terhadap orang, khususnya pendidikan formal dan pelatihan".

Todaro (2006:454) menyatakan bahwa "ada beberapa variabel penting lainnya yang kebanyakan bersifat non ekonomi (misalnya pengaruh tradisi budaya, gender, status sosial, pendidikan orang tua dan besarnya anggota keluarga) yang sangat mempengaruhi permintaan terhadap pendidikan".

Sedangkan Irianto (2011:56) menyatakan bahwa "permintaan pendidikan perorangan secara agregat dipengaruhi oleh faktor-faktor antara lain: pendapatan orang tua, pendidikan orang tua, pekerjaan orang tua, biaya pendidikan, kebijaksanaan umum (pemerintah), kebijaksanaan lembaga dan persepsi individu terhadap tiap-tiap jenis pendidikan". Permintaan pendidikan juga tergantung kepada cara pandangnya yaitu pendidikan itu dianggap sebagai konsumsi, sebagai investasi atau sebagai konsumsi dan investasi.

\section{METODE PENELITIAN}

Jenis penelitian Expost-Facto, menurut Sugiyono (2007:3) penelitian Expost-Facto adalah "penelitian yang dilakukan untuk meneliti peristiwa yang telah 
terjadi dan kemudian merunut ke belakang melalui data tersebut untuk menentukan faktor-faktor yang mendahului atau menentukan sebab-sebab yang mungkin atas peristiwa yang diteliti." Objek penelitian adalah pedagang toko/kios di Kota Padang. Masalah yang akan diteliti adalah pengaruh sosial ekonomi orang tua terhadap tingkat pendidikan anak pedagang toko/kios di Pasar Raya Kota Padang.

Populasi dalam penelitian ini adalah keseluruhan pedagang toko/kios di Pasar Raya Kota Padang yang berjumlah 2.337 pedagang toko/kios. Teknik pengambilan sampel purposive sampling yaitu sebanyak 342 orang pedagang dengan kriteria: 1) pedagang yang memiliki umur di atas 50 Tahun, 2) Pedagang yang memiliki anak bukan usia sekolah.

Teknik analisis data yang digunakan dalam penelitian ini adalah path analyis, dengan menggunakan sofware SPSS Versi 15.

\section{HASIL PENELITIAN DAN PEMBAHASAN}

Hasil analisis deskriptif menunjukkan bahwa rata-rata tingkat pendidikan anak pedagang Toko/kios di Pasar Kota Padang kebanyakan tamat SMA, SMK dan sejenisnya dan pendidikan Diploma atau Sarjana. Ratarata tingkat pendidikan orang tua (pedagang) Toko/kios di Pasar Kota Padang kebanyakan tamat SMA, SMK dan sejenisnya. Pendapatan orang tua (pedagang) Toko/kios di Pasar Kota Padang banyak berada pada kategori sedang. Motivasi orang tua (pedagang) Toko/kios di Pasar Raya Kota Padang masuk dalam kategori cukup, artinya bahwa para orang tua (pedagang) sudah cukup baik dalam memberikan motivasi kepada anak-anaknya mengenai pendidikan.

Setelah dilakukan uji syarat analisis terpenuhi yaitu uji normalitas dan uji homogenitas, dilanjutkan oleh uji hipotsis. Hasil uji hipotesis adalah: (1) Berdasarkan hasil analisis yang telah dihitung diperoleh nilai sig. $0,000<0.05$. Dengan memperhatikan kedua hasil tersebut, dapat diartikan bahwa tingkat pendidikan orang tua berpengaruh signifikan terhadap tingkat pendapatan orang tua (pedagang) Toko/kios di Pasar Raya Kota Padang. Dengan kata lain hipotesis yang telah diajukan dapat diterima pada $\alpha=0,05$, (2) Berdasarkan hasil analisis yang telah dihitung diperoleh nilai sig. $0,000<0.05$. Dengan memperhatikan kedua hasil tersebut, dapat diartikan bahwa tingkat pendidikan orang tua dan tingkat pendapatan orang tua berpengaruh signifikan terhadap motivasi orang tua (pedagang) Toko/kios di Pasar Raya Kota Padang. Dengan kata lain hipotesis yang telah diajukan dapat diterima pada $\alpha=0,05$, (3) Berdasarkan hasil analisis yang telah dihitung diperoleh nilai sig. $0,000<0.05$. Dengan memperhatikan kedua hasil tersebut, dapat diartikan bahwa tingkat pendidikan orang tua, tingkat pendapatan orang tua, dan motivasi orang tua berpengaruh signifikan terhadap tingkat pendidikan anak (pedagang) Toko/kios di Pasar Raya Kota Padang. Dengan kata lain hipotesis yang telah diajukan dapat diterima pada $\alpha=0,05$.

Berdasarkan uji hipotesis maka dilakukan pembahasan pada masing-masing hipotesis, yaitu sebagai berikut ini.

\section{Pengaruh Tingkat Pendidikan Orang tua Terhadap Tingkat Pendapatan Orang tua (Pedagang) Toko/kios di Pasar Raya Kota Padang}

Berdasarkan analisis yang dilakukan pada hipotesis pertama, diperoleh nilai sig. $0,000<0.05$, dapat diartikan bahwa tingkat pendidikan orang tua berpengaruh signifikan terhadap tingkat pendapatan orang tua (pedagang) Toko/kios di Pasar Raya Kota Padang. Dengan kata lain hipotesis yang telah diajukan dapat diterima pada $\alpha=0,05$, bahwa variabel tingkat pendidikan orang tua berpengaruh signifikan terhadap tingkat pendapatan orang tua. Koefisien jalur variabel tingkat pendidikan orang tua (X1) terhadap tingkat pendapatan orang tua (X2) menunjukkan angka yang positif, hal ini berarti koefisien jalur tersebut memperlihatkan bahwa tingkat pendidikan orang tua memiliki pengaruh signifikan 
terhadap tingkat pendapatan orang tua pada $\alpha=0.05$.

Hasil penelitian ini sejalan dengan pendapat Todaro dan Smith, (2003:90) menyatakan bahwa aspek pendidikan memiliki tugas dan kewajiban untuk membentuk kepribadian, watak, moral, nilainilai kejujuran, cinta bangsa dan negara, empati terhadap sesama yang memiliki perbedaan etnis, agama, dan kultural. Salah satu indikator untuk mengukur pendidikan adalah rata-rata lama sekolah (years of schooling). Rata-rata lama sekolah adalah sebuah angka yang menunjukkan lamanya bersekolah seseorang dari masuk sekolah dasar sampai dengan tingkat pendidikan terakhir. Lamanya bersekolah merupakan ukuran akumulasi investasi pendidikan individu. Setiap tahun tambahan sekolah diharapkan akan membantu meningkatkan pendapatan seseorang.

Menurut Blaug (dalam Elfindri, 2001:20) "teori modal manusia menyatakan bahwa lamanya masa pendidikan dan semakin lamanya akumulasi pengalaman berkorelasi positif dengan pendapatan". Individu yang memiliki pendidikan yang relatif lama memiliki pendapatan yang lebih tinggi bilamana dibandingkan dengan individu yang tidak memiliki pendidikan formal.

Hasil penelitian ini sejalan dengan penelitian yang dilakukan oleh Tarigan (2004:222) menyatakan manfaat pendidikan adalah adanya peningkatan tingkat pendapatan apabila mengikuti pendidikan yang lebih tinggi jenjangnya dan anak didik secara sadar atau tidak sadar akan menebarkan pengetahuannya kepada masyarakat sekitarnya.

Pendidikan berpengaruh terhadap kecakapan, tingkah laku dan sikap seseorang, dan hal ini semestinya terkait dengan tingkat pendapatan seseorang. Artinya secara ratarata makin tinggi tingkat pendidikan seseorang maka makin memungkinkan orang tersebut memperoleh pendapatan yang lebih tinggi.
Tingkat pendidikan pedagang dalam penelitian ini berpengaruh signifikan terhadap tingkat pendapatannya, hal ini terlihat bahwa pedagang yang memiliki pendidikan tinggi lebih tinggi pendapatannya dibandingkan dengan pedagang yang memiliki pendidikan yang rendah. Seorang pedagang yang memiliki pendidikan tinggi sikap dan pola mereka berdagang akan berbeda dengan pedagang yang memiliki pendidikan yang rendah

Umumnya pedagang yang berpendidikan tinggi lebih memiliki inovasi dalam kegiatan perdagangannya, hal ini karena cara pandang seorang pedagang yang memiliki pendidikan tinggi lebih memiliki kreativitas dibandingkan dengan pedagang yang berpendidikan rendah. Hal ini nantinya akan berpengaruh terhadap tingkat pendapatan yang diperoleh oleh pedagang tersebut.

Hasil analisis deskriptif menunjukkan bahwa tingkat pendapatan orang tua (pedagang) Toko/kios di Pasar Raya Kota Padang banyak berada pada kategori sedang dengan rentangan interval pendapatan $\mathrm{Rp}$. 4.266.001-Rp.6.266.000 dan juga berada pada kategori tinggi yaitu Rp. 6.266.001Rp.8.266.000. Sedangkan rata-rata tingkat pendidikan orang tua (pedagang) Toko/kios di Pasar Kota Padang kebanyakan tamat SMA, SMK dan sejenisnya.

Selanjutnya besarnya pengaruh tidak langsung tingkat pendidikan orang tua melalui pendapatan terhadap tingkat pendidikan anak lebih besar yaitu 9,63\% dibandingkan pengaruh tidak langsung tingkat pendidikan orang tua melalui motivasi orang tua terhadap pendidikan anak yaitu sebesar 8,26\%. Ini menunjukkan bahwa pendapatan orang tua memberikan peran yang besar terhadap peningkatan tingkat pendidikan anak.

\section{Pengaruh Tingkat Pendidikan dan Pendapatan Orang tua terhadap Motivasi Orang tua (Pedagang) Toko/kios di Pasar Raya Kota Padang}


Berdasarkan hasil analisis diperoleh nilai sig. $0,000<0.05$, artinya tingkat pendidikan orang tua dan tingkat pendapatan orang tua secara bersama-sama berpengaruh signifikan terhadap motivasi orang tua (pedagang) Toko/kios di Pasar Raya Kota Padang. Dengan kata lain hipotesis yang telah diajukan dapat diterima pada $\alpha=0,05$. Koefisien jalur variabel tingkat pendidikan orang tua (X1) terhadap motivasi orang tua (X3) adalah positif, hal ini berarti koefisien jalur tersebut memperlihatkan bahwa tingkat pendidikan orang tua memiliki pengaruh signifikan terhadap motivasi orang tua pada $\alpha$ $=0.05$. Begitu juga dengan koefisien jalur variabel tingkat pendapatan orang tua (X2) terhadap motivasi orang tua (X3) adalah positif, hal ini berarti koefisien jalur tersebut memperlihatkan bahwa tingkat pendapatan orang tua memiliki pengaruh signifikan terhadap motivasi orang tua pada $\alpha=0.05$

Berdasarkan hasil penelitian Fathoni (2008:70) terdapat beberapa faktor yang mempengaruhi keberlanjutan pendidikan atau mempengaruhi tingkat pendidikan. Dalam penelitian tersebut dikatakan bahwa beberapa faktor yang mempengaruhi tingkat pendidikan. Faktor-faktor tersebut terbagi menjadi dua bagian yaitu faktor internal (keluarga dan orang tua) dan faktor eksternal (lingkungan serta sarana informasi). Faktor internal terdiri dari beberapa hal yaitu umur kepala keluarga, tingkat pendidikan kepala keluarga, besar keluarga (besar tanggungan), total pendapatan keluarga, total pengeluaran keluarga, persepsi tentang arti penting sekolah, persepsi tentang biaya pendidikan, dan status usaha kepala keluarga. Faktor eksternal terdiri dari kebijakan pemerintah, informasi terhadap pendidikan, sarana pendidikan, serta jarak sarana pendidikan.

Tingkat pendidikan orang tua dan pendapatan orang tua berpengaruh signifikan terhadap motivasi orang tua. Orang tua yang memiliki tingkat pendidikan yang tinggi biasanya memiliki keinginan atau motivasi terhadap tingkat pendidikan anaknya agar anaknya memiliki tingkat pendidikan yang tinggi pula. Begitu juga dengan tingkat pendapatan orang tua, orang tua yang memiliki tingkat pendapatan yang tinggi biasanya memiliki motivasi tinggi terhadap pendidikan anaknya.

Hasil analisis deskriptif menunjukkan bahwa rata-rata skor variabel motivasi orang tua (pedagang) Toko/kios di Pasar Raya Kota Padang adalah 3,92 dengan tingkat pencapaian jawaban responden sebesar 78,38\%. Hal ini menunjukkan bahwa motivasi orang tua (pedagang) di Pasar Raya Kota Padang masuk dalam kategori cukup. Dari keempat indikator dalam variabel motivasi orang tua (pedagang) di Pasar Kota Padang, hanya 1 indikator mempunyai tingkat capaian jawaban responden dengan kategori baik yaitu pemberian nasehat dan tiga indikator lainnya mempunyai tingkat capaian jawaban responden dengan kategori cukup yaitu indikator pemberian perhatian, pemberian hadiah, dan pemberian hukuman. Ini berarti motivasi orang tua (pedagang) Toko/kios di Pasar Kota Padang jika diukur dari keempat indikator ini masih belum maksimal.

Pengaruh tidak langsung tingkat pendidikan orang tua terhadap tingkat pendidikan anak melalui motivasi orang tua sebesar 8,26\% lebih besar dibandingkan pengaruh tidak langsung tingkat pendapatan orang tua terhadap tingkat pendidikan melalui motivasi orang tua sebesar $6,04 \%$. Hal ini mengindikasikan bahwa tingkat pendidikan orang tua lebih besar dampaknya terhadap tingkat pendidikan anak melalui variabel motivasi orang tua, dibandingkan dengan tingkat pendapatan orang tua. Artinya orang tua yang memiliki tingkat pendidikan yang tinggi memiliki motivasi yang lebih baik dan lebih tinggi dibandingkan dengan faktor pendapatan.

\section{Pengaruh Tingkat Pendidikan Orang tua, Tingkat Pendapatan Orang tua, dan Motivasi Orang tua terhadap Tingkat Pendidikan Anak Pedagang di Pasar Raya Kota madang \\ Berdasarkan hasil analisis diperoleh} bahwa nilai sig. Sebesar $0,00<0,05$, artinya 
pada hipotesis ketiga terdapat pengaruh yang signifikan tingkat pendidikan orang tua, tingkat pendapatan orang tua, dan motivasi orang tua terhadap tingkat pendidikan anak pedagang Toko/kios di Pasar Raya Kota Padang. Koefisien jalur variabel tingkat pendidikan orang tua (X1), tingkat pendapatan orang tua (X2), dan motivasi orang tua (X3) adalah positif, hal ini berarti koefisien jalur tersebut memperlihatkan bahwa tingkat pendidikan orang tua, tingkat pendapatan orang tua, dan motivasi orang tua memiliki pengaruh signifikan terhadap tingkat pendidikan anak pada $\alpha=0.05$. Sehingga dapat disimpulkan bahwa untuk peningkatan tingkat pendidikan anak dapat dipengaruhi oleh adalah tingkat pendidikan orang tua, tingkat pendapatan orang tua, dan motivasi orang tua.

Todaro (2006:454) menyatakan bahwa "ada beberapa variabel penting lainnya yang kebanyakan bersifat non ekonomi (misalnya pengaruh tradisi budaya, gender, status sosial, pendidikan orang tua dan besarnya anggota keluarga) yang sangat mempengaruhi permintaan terhadap pendidikan". Sedangkan Irianto (2011:56) menyatakan bahwa "permintaan pendidikan perorangan secara agregat dipengaruhi oleh faktor-faktor antara lain: pendapatan orang tua, pendidikan orang tua, pekerjaan orang tua, biaya pendidikan, kebijaksanaan umum (pemerintah), kebijaksanaan lembaga dan persepsi individu terhadap tiap-tiap jenis pendidikan". Permintaan pendidikan juga tergantung kepada cara pandangnya yaitu pendidikan itu dianggap sebagai konsumsi, sebagai investasi atau sebagai konsumsi dan investasi.

Hasil penelitian ini sejalan dengan penelitian yang dilakukan oleh Bahar (2000:131) tingkat pendidikan anak mempunyai korelasi yang tinggi dengan tingkat sosial ekonomi orang tua, sebab segala kebutuhan anak yang berkenaan dengan pendidikan selalu membutuhkan sosial ekonomi keluarga, dengan artian secara umum bahwa pendidikan membutuhkan uang untuk meningkatkan pendidikan anak. Menurut Tan faktor-faktor yang mempengaruhi sosial ekonomi orang tua meliputi: pendidikan, pendapatan, dan pekerjaan orang tua. Jadi orang tua yang memiliki sosial ekonomi yang tinggi akan lebih meningkatkan pendidikan anaknya.

Hasil penelitian juga konsisten dengan penelitian yang dilakukan oleh Mustamin (2010), tingkat pendidikan orang tua, pendapatan orang tua berpengaruh significan terhadap tingkat pendidikan anak di Pemukiman Kumuh Kota Makasar. Penelitian yang dilakukan oleh Jatmiko (2012) mengenai pengaruh kondisi social ekonomi terhadap tingkat pendidikan anak pada keluarga buruh batik, petani, dan nelayan di Kecamatan Wiradesa Kabupaten Pekalongan.

Sejalan juga dengan penelitian yang dilakukan oleh Basrowi dan Siti Juariyah (2010) mengenai analisis kondisi sosial ekonomi dan tingkat pendidikan masyarakat Desa Srigading, Kecamatan Labuhan Maringgai, Kabupaten Lampung Timur.

Tingkat pendidikan orang tua dalam penelitian ini berpengaruh signifikan terhadap tingkat pendidikan anak. Pedagang yang memliki tingkat pendidikan yang tinggi dan pendidikan yang rendah akan berbeda cara dan pola asuhnya terhadap anak, pedagang yang memiliki tingkat pendidikan yang tinggi biasanya akan memberikan pandangan dan motivasi mengenai pendidikan kepada anakanaknya, begitu juga sebaliknya. Pedagang yang memiliki tingkat pendidikan yang rendah, biasanya tidak begitu termotivasi terhadap tingkat pendidikan anaknya, hal ini dikarenakan pengetahuan dan cara pandang yang dimilikinya.

Tingkat pendapatan dalam penelitian ini berpengaruh signifikan terhadap tingkat pendidikan anak. Pada hakikatnya tingkat pendapatan orang tua merupakan perolehan hasil dari kegiatan ekonomi orang tua. Ekonomi orang tua mempunyai peranan terhadap pembentukan anak. Misalnya pedagang yang perekonomiannya cukup, menyebabkan lingkungan materialnya yang dihadapi anak di dalam keluarganya akan 
lebih luas, sehingga ia mendapat kesempatan yang lebih banyak dalam mengembangkan bermacam-macam kecakapan. Hubungan sosial antara anak-anak dengan orang tuanya ternyata berlainan juga dalam bentukbentuknya, misalnya keluarga yang ekonominya cukup, hubungan antara orang tua dan anak-anaknya akan lebih baik sebab orang tua tidak tertekan di dalam mencapai kebutuhan-kebutuhan hidupnya sehingga perhatiannya dapat dicurahkan kepada anakanaknya. Jadi orang tua dalam hal ini mencurahkan perhatian yang lebih mendalam kepada pendidikan anaknya karena tidak disulitkan dengan perkara kebutuhan primer kehidupan manusia.

Begitu juga dengan motivasi orang tua, orang tua atau pedagang yang memiliki motivasi tinggi terhadap pendidikan anaknya akan berdampak terhadap tingkat pendidikan anak-anaknya. Karena dengan motivasi orang tua yang tinggi maka orang tua akan memberikan pandangan mengenai pendidikan kepada anaknya, dan juga mendorong anakanaknya untuk memperoleh pendidikan yang tinggi.

Hasil penelitian ini sejalan dengan penelitian yang dilakukan oleh Udiyono (2011) mengenai pengaruh motivasi orang tua, kondisi lingkungan dan disiplin belajar terhadap prestasi akademik mahasiswa pendidikan matematika Universitas Widya Dharma Klaten semester Gasal Tahun Akademik 2010/2011.

Hasil analisis deskriptif menunjukkan bahwa rata-rata tingkat pendidikan anak pedagang di Pasar Kota Padang kebanyakan tamat SMA, SMK dan sejenisnya dan pendidikan Diploma atau Sarjana. Dari 342 orang pedagang sebanyak 309 orang pedagang memiliki anak dengan rata-rata tingkat pendidikan atas dan pendidikan tinggi.

Ditinjau berdasarkan analisis jalur pengaruh langsung dan tidak langsung variabel tingkat pendapatan orang tua terhadap tingkat pendidikan anak lebih kecil dari pada variabel tingkat pendapatan orang tua terhadap tingkat pendidikan anak melalui motivasi orang tua. Hal ini berarti bahwa peningkatan tingkat pendidikan anak dapat dilakukan dengan peningkatan terhadap tingkat pendapatan orang tua dan juga harus mempertimbangkan motivasi orang tua.

Lebih lanjut berdasarkan analisis jalur pengaruh langsung variabel motivasi orang tua sebesar 23,23\%. Hal ini berarti bahwa peningkatan motivasi orang tua yang dilakukan akan berdampak langsung terhadap peningkatan tingkat pendidikan anak.

\section{PENUTUP}

\section{Simpulan}

Berdasarkan hasil penelitian yang dilakukan untuk mengetahui pengaruh status sosial ekonomi orang tua dan motivasi orang tua terhadap tingkat pendidikan anak pedagang toko/kios di Pasar Raya Kota Padang diperoleh kesimpulan sebagai berikut: (1) Tingkat pendidikan orang tua berpengaruh signifikan terhadap tingkat pendapatan orang tua (pedagang) toko/kios di Pasar Raya Kota Padang, (2) Tingkat pendidikan orang tua dan pendapatan orang tua berpengaruh signifikan terhadap motivasi orang tua (pedagang) toko/kios di Pasar Raya Kota Padang, (3) Tingkat pendidikan orang tua, tingkat pendapatan orang tua, dan motivasi orang tua berpengaruh signifikan terhadap tingkat pendidikan anak pedagang toko/kios di Pasar Raya Kota Padang.

\section{Saran}

Berdasarkan temuan penelitian ini, peneliti mengemukakan atau mengajukan beberapa saran sebagai berikut: (1) Tingkat pendidikan orang tua berpengaruh terhadap tingkat pendidikan anknya, untuk itu tingkat pendidikan sangatlah penting. Orang tua yang memiliki tingkat pendidikan yang tinggi biasanya akan memberikan pandangan yang lebih baik terhadap pendidikan anaknya, (2) Tingkat pendapatan orang tua berpengaruh terhadap tingkat pendidikan anaknya, sehinggah perlu adanya usaha dari orang tua untuk memperoleh pendapatan yang tinggi 
agar mampu menyekolahkan anak-anaknya ke perguruan tinggi, (3) Kepada orang tua (pedagang) Toko/Kios di Pasar Raya Kota Padang untuk selalu memberikan motivasi kepada anaknya agar memperoleh pendidikan tinggi, dengan cara memberikan perhatian, memberikan hadiah jika anaknya berhasil dalam belajar, dan memberikan hukuman atau teguran kepada anak yang tidak disiplin dalam belajar, (4) Kepada peneliti yang berminat untuk mengembangkan penelitian ini, dapat memasukkan variabel lain untuk diteliti seperti: jenis pekerjaan orang tua, motivasi anak dalam melanjutkan pendidikan, dan jumlah tanggungan keluarga.

\section{DAFTAR PUSTAKA}

10.22202/economica.2015.v4.i1.270

Basrowi dan Siti Juariyah. 2010. Analisis Kondisi Sosial Ekonomi dan Tingkat Pendidikan Masyarakat Desa Srigading, Kecamatan Labuhan Maringgai, Kabupaten Lampung Timur. Jurnal Ekonomi \& Pendidikan, Volume 7 Nomor 1, April 2010.

Danim, Sudarwan. 2003. Ekonomi Sumber Daya Manusia. Jakarta : Pustaka Setia.

Depdiknas. 2008. UU No.20 tahun 2003 tentang Sistem Pendidikan Nasional. Jakarta: Sinar Grafika.

Elfindri. 2001. Ekonomi Sumber Daya Manusia. Padang : Universitas Andalas.

Fattah, Nanang. 2009. Ekonomi dan Pembiayaan Pendidikan. Bandung: Remaja Rosda Karya.

Irianto, Agus. 2011. Pendidikan sebagai Investasi dalam Pembangunan Suatu Bangsa. Jakarta: Kencana Pranada Media Group.

Sugiyono. 2007. Metode Penelitian Bisnis. Bandung: CV. Alfa Beta.
Suryani, N. 2004. Pengantar Sosiologi Masyarakat Pesisir. Jakarta: Cidesindo.

Tarigan, Robinson. 2006. Pengaruh Tingkat Pendidikan Terhadap Tingkat Pendapatan Perbandingan Antara Empat Hasil Penelitian. Jurnal Wawasan, Februari 2006, Volume 11, Nomor 3.

Todaro, Michael.P. 2006. Pembangunan Ekonomi Jilid 1 Edisi Kesembilan. Jakarta : Erlangga.

Udiyono (2011). Pengaruh Motivasi Orang tua, Kondisi Lingkungan dan Disiplin Belajar Terhadap Prestasi Akademik Mahasiswa Pendidikan Matematika Universitas Widya Dharma Klaten semester Gasal Tahun Akademik 2010/2011. Magistra No. 75 Th. XXIII Maret 201193 ISSN 0215-9511.

Undang-Undang RI No. 20 Tahun 2003. Sistem Pendidikan Nasional. Jakarta: Asokadikta dan Durat Bahagia.

Yahya. 2009. Ekonomi Dan Pembiayaan Pendidikan: Sebuah Pendekatan Akumulatif. Jakarta. Sukabina. 